\title{
Analisis Karakteristik Sedimen Melayang dan Sedimen Dasar pada Sungai Bompon untuk Pengelolaan DAS Terpadu di Sub DAS Bompon, Kabupaten Magelang, Jawa Tengah
}

\author{
Maola Maqdan, a), Ekha Yogafanny ${ }^{1, \text { b) }}$, Andi Sungkowo ${ }^{1)}$, M. Anggri Setiawan ${ }^{2,4)}$, Junun Sartohadi ${ }^{3,4)}$ \\ 1) Teknik Lingkungan, Fakultas Teknologi Mineral, UPN Veteran Yogyakarta \\ 2) Geografi Lingkungan, Fakultas Geografi, Universitas Gadjah Mada Yogyakarta \\ 3) Ilmu Tanah, Fakultas Pertanian, Universitas Gadjah Mada Yogyakarta \\ 4) Transbulent Research Group
}

Email korespondensi: ${ }^{\text {a) }}$ maolamaqdan@ gmail.com; ${ }^{\text {b) }}$ ekha.yogafanny@upnyk.ac.id

\begin{abstract}
ABSTRAK
Proses geomorfologi seperti erosi dan longsor sangat aktif terjadi di Sub DAS Bompon yang berada di Kabupaten Magelang, Jawa Tengah. Material yang tererosi tersebut tersedimentasi di Sungai Bompon. Material sedimen yang berada pada Sungai Bompon berasal dari tanah permukaan yang tererosi, erosi tebing sungai, dan erosi dasar sungai. Karakteristik sedimen yang berada di Sungai Bompon perlu diketahui guna mengetahui upaya pengelolaan daerah aliran sungai terpadu. Tujuan penelitian ini untuk menganalisis karakteristik sedimen melayang dan sedimen dasar pada sungai Bompon pada bagian hulu, tengah dan hilir. Metode yang digunakan dalam penelitian ini yaitu metode survei, metode pemetaan, metode analisis laboratorium dan metode matematis. Hasil penelitian menunjukan bahwa debit muatan sedimen melayang pada bagian hulu sungai rata-rata sebesar 55,322 ton/tahun dengan hubungan antara debit aliran dan debit muatan sedimen melayang yang dirumuskan dalam Qs $=9,12119 \mathrm{Q}-0,12828$ dengan $\mathrm{r}$ (korelasi) $=0,9768$. Debit muatan sedimen dasar pada hulu sungai rata-rata sebesar 0,323 ton/tahun. Pada bagian tengah sungai, debit muatan sedimen melayang memiliki rata-rata sebesar 945,570 ton/tahun dengan hubungan antara debit aliran dan debit muatan sedimen melayang dapat dirumuskan dalam Qs $=23,9113$ Q $-0,58204$ dengan $\mathrm{r}$ (korelasi) = 0,98178. Debit muatan sedimen dasar pada bagian tengah sungai rata-rata sebesar 2,077 ton/tahun. Pada bagian hilir sungai, debit muatan sedimen melayang memiliki rata-rata sebesar 8297,002 ton/tahundengan hubungan antara debit aliran dan debit muatan sedimen melayang dapat dirumuskan dalam $\mathrm{Qs}=42,3715 \mathrm{Q}-1,14840$ dengan $\mathrm{r}$ (korelasi) $=0,95373$ dan debit muatan sedimen dasar yang dihasilkan rata-rata sebesar 5,975 ton/tahun.
\end{abstract}

Kata Kunci: sedimen dasar; sedimen melayang; sub DAS Bompon.

\section{ABSTRACT}

Geomorphological processes such as erosion and landslides have been actively occurred in the Bompon subwatershed located in Magelang Regency, Central Java. Some of the eroded materials are sedimentation the Bompon River. Bedload material on the Bompon River originates from the eroded soil surface, riverbank erosion, and riverbed erosion. The sediment characteristics in the Bompon River need to be investigated to find out the integrated watershed management. The purpose of this study was to analyze the characteristics of floating sediments and bedload sediments in Bompon River in the upstream, middle stream, and downstream parts. The methods used in this research were survey method, mapping method, laboratory analysis method, and mathematical method. The results showed that the average discharge of suspended load in the upstream was 55,322 tons/year and the relationship between flow discharge and suspended load discharge was formulated in $Q s=9.12119 Q-0.12828$ with $r$ (correlation) $=0.9768$. The average discharge of bedload sediment in the upstream reached 0.323 tons/year. In the middle stream of the river, the average suspended load discharge was 945,570 tons/year with the relationship between flow discharge and suspended load discharge can be formulated in $Q s=23.9113 Q-0.58204$ with $r$ (correlation) $=0.98178$. The average discharge of bedload in the middle stream of the river was 2,077 tons/year. In the downstream, the average discharge of suspended load was 8,297,002 tons/year with the relationship between flow discharge and suspended load discharge can be formulated in $Q s=42,3715 Q-1,14840$ with $r$ (correlation) $=0.95373$ and the average discharged of bedload sediment was 5,975 tons/year.

Keywords: bedload; Bompon Sub-Catchment; suspended load. 


\section{PENDAHULUAN}

Sungai Bompon yang berada di Kabupaten Magelang, Jawa Tengah mengalir dari utara ke selatan sepanjang $8,191 \mathrm{~km}$ dapat dilihat pada Gambar 1. Kekeruhan pada bagian hulu sungai adalah 9,00 NTU, bagian tengah sungai adalah 52,00 NTU dan kekeruhan pada bagian hilir sungai adalah 421,00 NTU. Konsentrasi Total Suspended Solid (TSS) pada bagian hulu sungai adalah $30 \mathrm{mg} / \mathrm{l}$, bagian tengah sungai adalah $36 \mathrm{mg} / \mathrm{l}$ dan TSS pada bagian hilir sungai adalah $32 \mathrm{mg} / \mathrm{l}$. Pembagian sungai dari hulu sampai hilir dapat dilihat pada Gambar 2. Hasil pengujian kualitas air sungai ini disesuaikan dengan kualitas air Kelas 3 (pembudidayaan ikan air tawar, peternakan, air untuk mengairi pertanaman, dan atau peruntukan lain yang mempersyaratkan mutu air yang sama dengan kegunaan tersebut) Peraturan Pemerintah Nomor 82 Tahun 2001 Tentang Pengelolaan Kualitas Air dan Pengendalian Pencemaran Air.Nilai bakumutu TSS pada kelas tersebut yaitu $400 \mathrm{mg} / \mathrm{l}$, sehingga nilai TSS pada air sungai tersebut tidak melebihi nilai bakumutu untuk peruntukannya.

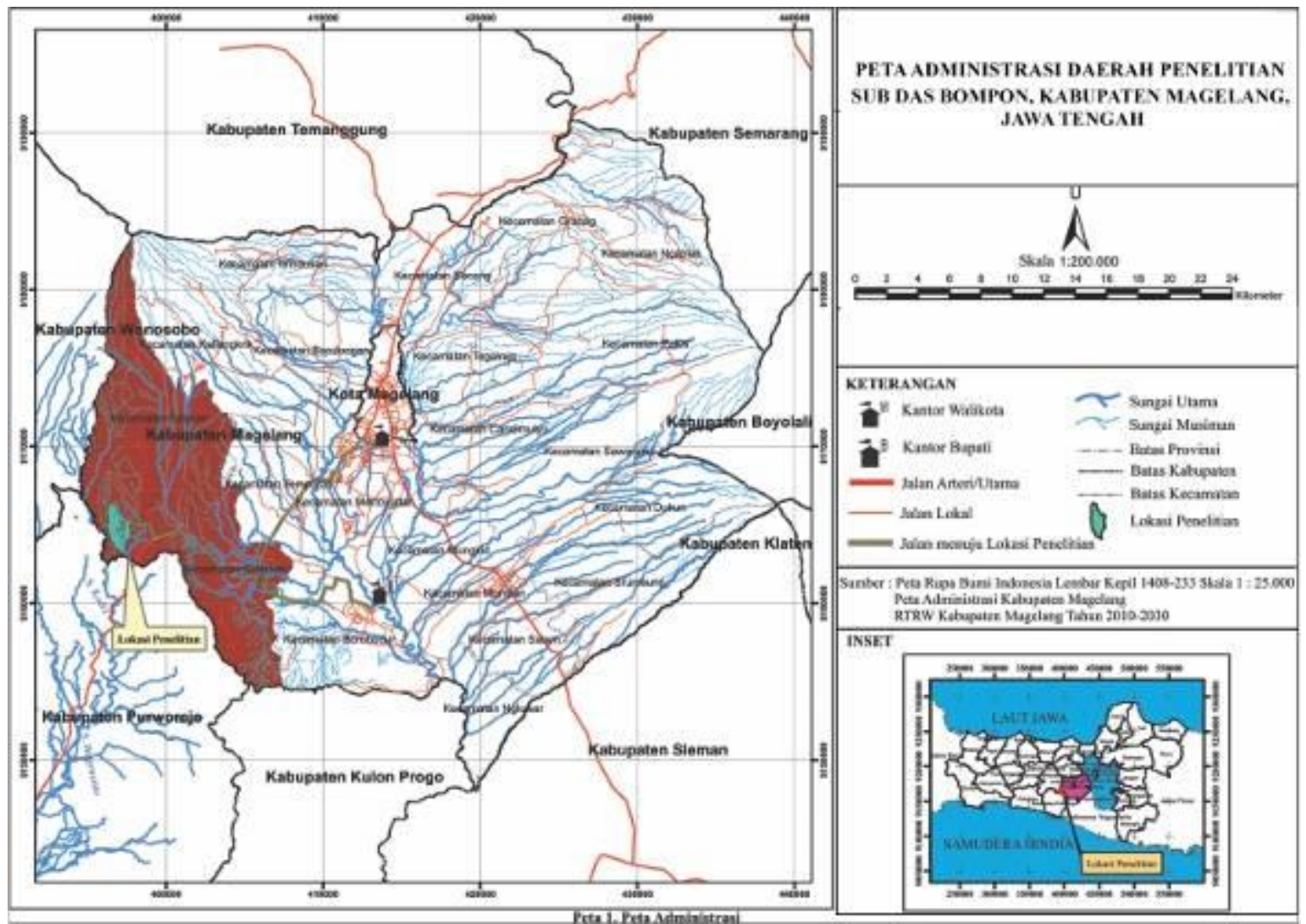

Gambar 1. Peta Administrasi Daerah Penelitian Sub DAS Bompon Kabupaten Magelang, Jawa Tengah

Namun demikian, kekeruhan yang tinggi dapat menyebabkan terganggunya daya lihat organisme akuatik dan sistem pernafasan, serta dapat menghambat penetrasi cahaya ke dalam air (Effendi, 2003).Jika suatu perairan memiliki nilai kekeruhan dan TSS yang tinggi maka semakin rendah nilai produktivitas suatu perairan tersebut. Hal ini berhubungan dengan proses fotosintesis dan respirasi yang terjadi pada organisme di perairan (Winnarsih dan Afu, 2016). Selain itu, tingginya nilai kekeruhan dan TSS dapat mengurangi estetika lingkungan sungai.

Material dan sumber material yang menyebabkan tingginya nilai kekeruhan dan TSS perlu diketahui agar dapat menentukan upaya pengelolaan sungai dan Sub DAS di suatu daerah. Salah satu material penyebab kekeruhan sungai adalah tanah.Jenis tanah dan pengelolaan tanah/ lahan sangat berpengaruh terhadap tingkat erosi.Jenis tanah pada Sub DAS Bompon termasuk tanah latosol.Tanah latosol adalah tanah yang memiliki tekstur tanah berupa liat/ lempung sehingga memiliki ketahanan terhadap erosi (Febiansyah, dkk, 2018). Wilayah Sub DAS Bompon memiliki nilai ambang batas erosi/ kerusakan tanah sangat rendahyang memiliki nilai 0,22 - 0,93 $\mathrm{mm} /$ tahun (Sambodo dan Setiawan, 2016). Hal ini dipengaruhi adanya erosi aktual (erosi yang disebabkan adanya campur tangan manusia) yang cukup intensif serta nilai indeks produktivitas aktual Sub DAS Bompon yang rendah yang disebabkan oleh kandungan lempung di Sub DAS ini. 

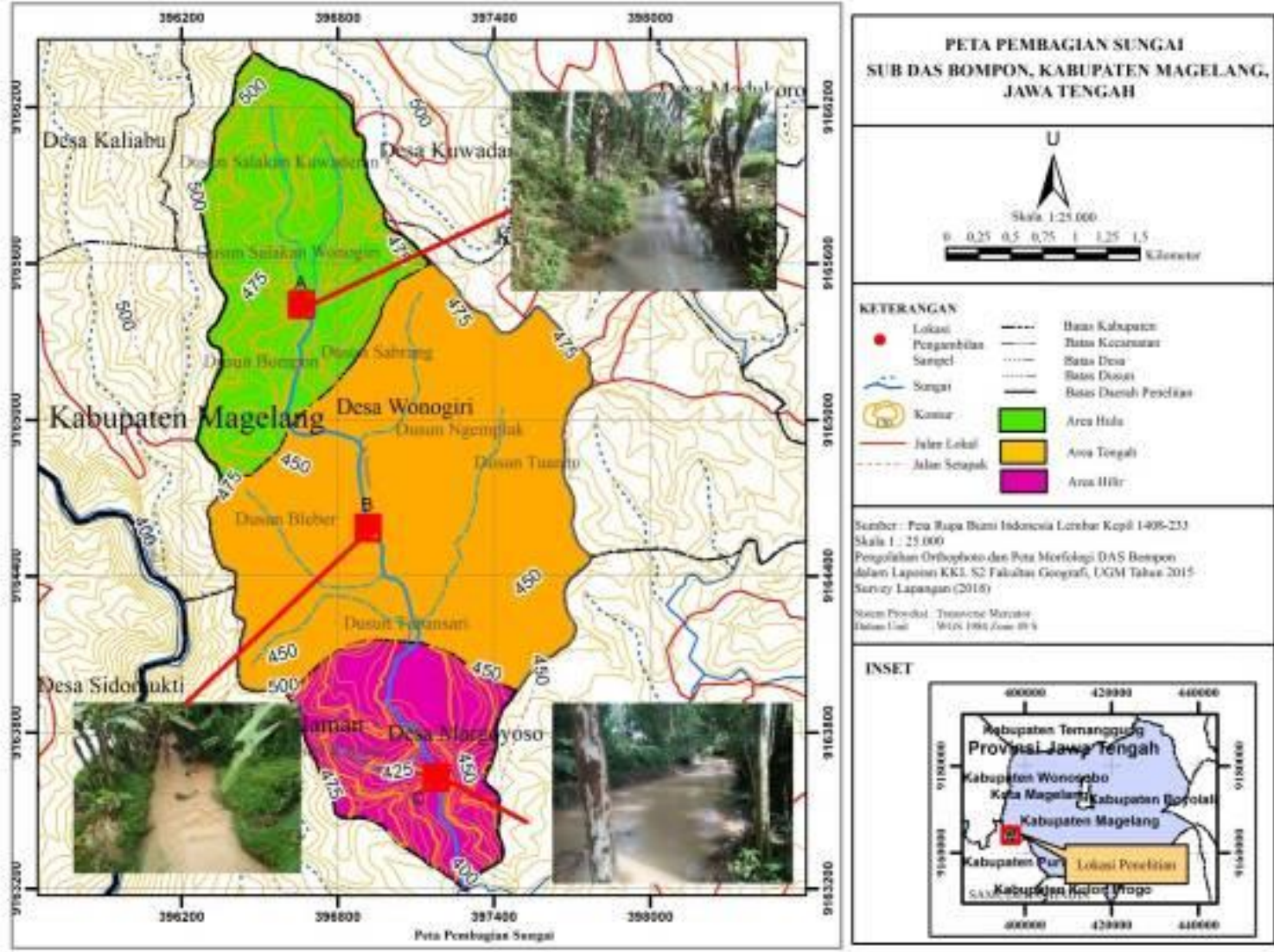

Gambar 2. Peta Pembagian Sungai Sub DAS Bompon Kabupaten Magelang, Jawa Tengah

Penggunaan lahan pada Sub DAS Bomponadalahkebun campuran, permukiman, sawah irigasi dan tegalanyang dapat dilihat pada Gambar 3. Penggunaan lahan yang mendominasi pada Sub DAS Bompon adalah kebun campuran yaitu sebesar 76,23\% dari luas area penelitian. Kebun campuran adalah kebun yang ditanami berbagai jenis tanaman yang berupa tanaman tahunan dan/ atau tanaman setahun yang tumbuh sendiri maupun ditanam dan dibiarkan hidup selama tidak mengganggu tanaman pokok dengan minimal satu jenis tanaman berkayu (Martini, dkk, 2010). Dilihat dari penelitian Rokhmaningtyas dan Setiawan (2017), laju kehilangan tanah yang terjadi secara signifikan di Sub DAS Bompon terjadi pada penggunaan lahan kebun campuran yang ditanami ketela dan sengon dengan karakteristik tanah yang sangat gembur, model pertanian yang berteras, pengolahan lahan yang sangat intensif serta tidak ada vegetasi rendah ataupun seresah.

Berdasarkan hasil pengamatan dilapangan, muatan material sedimen yang berada pada Sungai Bompon bukan hanya berasal dari penggunaan lahan tetapi juga berasal dari erosi tebing sungai dan erosi dasar sungai.Berdasarkan muatan sedimennya, dibedakan menjadi 2 yaitumuatan sedimen melayang (suspended load), dan muatan sedimen dasar (bed load).Muatan sedimen melayang dapat dilihat sebagai material dasar sungai (bed material) yang berukuran butiran-butiran pasir halus yang melayang di dalam aliran sungai,dan hanya sedikit sekali interaksinya dengan dasar sungai, karena selalu didorong ke atas oleh turbulensi aliran.Muatan sedimen dasar dapat dilihat sebagai partikel-partikel kasar yang bergerak sepanjang dasar sungai.Adanya muatan sedimen dasar dapat ditunjukan dengan adanyagerakan partikel-partikel pada dasar sungai. Gerakan pada partikelpartikeldapat berupapergeseran, menggelinding, atau meloncat-loncat, akan tetapi tidak pernah lepas dari dasar sungai. Bahkan gerakan ini kadang-kadang dapat sampai jarak tertentu dengan ditandai bercampurnya butiran partikel tersebut bergerak ke arah hilir (Soewarno, 1991 dalam Sembiring, dkk, 2014).

Pengelolaan sungai dalam suatu DAS sangat penting untuk dilakukan guna menndukung pengelolaan DAS yang berkelanjutan.Kajian terkait sedimen suatu sungai dalam suatu DAS perlu dilakukan sebagai dasar dalam menentukan arahan pengelolaan DAS.Dengan demikian penelitian ini bertujuan untuk menganalisis karakteristik sedimen melayang dan sedimen dasar pada sungai Bompon pada bagian hulu, tengah dan hilir. 


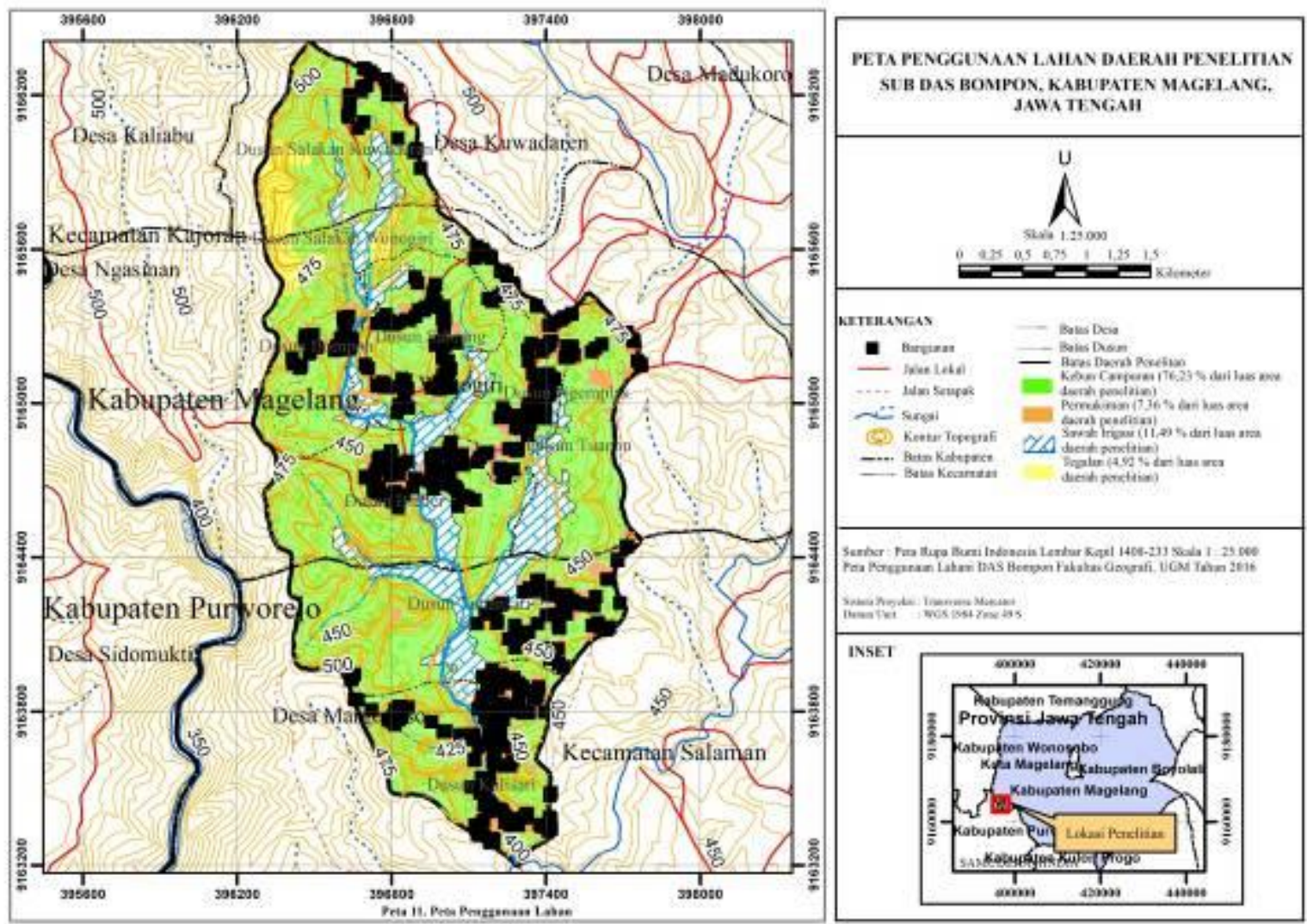

Gambar 3. Peta Penggunaan Lahan Sub DAS Bompon Kabupaten Magelang, Jawa Tengah

\section{METODE}

Metode yang digunakan pada penelitian ini adalah survei, pemetaan, analisis laboratorium dan matematis, sebagai berikut :

- Metode survei bertujuan untuk mendapatkan data primer dan data sekunder baik dari instansi pemerintah ataupun dengan melakukan pengecekan, pengamatan, pencarian informasi terkait dengan objek penelitian. Survei data sekunder bertujuan untuk mengumpulkan data dan peta yang tersedia pada berbagai instansi terkait sesuai dengan rumusan masalah dan sebagai dasar untuk melakukan survei lapangan. Data sekunder yang diperlukan antara lain Peta Jenis Tanah Provinsi Jawa Tengah, Peta Rupabumi Indonesia, Peta Geologi Regional dan peta-peta tematik lain. Survei yang dilakukan untuk mendapatkan data sekunder tersebut adalah dengan meminta ke intansi terkait dan melakukan pencarian dan pengunduhan. Hasil survei lapangan ditampilkan dalam bentuk peta, tabel dan analisis deskiptif. Survei data primer bertujuan untuk membandingkan data sekunder yang sudah didapat dengan kondisi dilapangan.Data primer yang dimaksud adalahpenggunaan lahan, tekstur tanah, debit sungai, ukuran butir, berat jenis sedimen, kadar muatan melayang, debit muatan sedimen melayang dan debit muatan sedimen dasar.Survei yang dilakukan untuk mendapatkan data primer tersebut adalah dengan melakukan pengukuran debit sungai dengan pelampung, melakukan pengamatan langsung dilapangan dan menguji tekstur tanah, mengambil sampel sedimen melayang dan sedimen dasar.

- Metode pemetaan bertujuan untuk menyajikan data lapanganberupa peta, contohnya adalah peta penggunaan lahan, dan peta pembagian sungai. Peta-peta tersebut diperoleh dari data sekunder yang sudah didapatkan, kemudian melakukan cross check untuk menyempurnakan peta tersebut. 
- Metode analisis laboratorium bertujuan untuk mengetahui berat jenis sedimen, berat basah sedimen melayang, berat kering sedimen melayang dan ukuran butir sedimen. Alat dan bahan yang digunakan pada penelitian ini antara lain berupa botol sampling, kertas filter yang digunakan untuk menyaring sampelsedimen melayang, oven pengering yang digunakan untuk mengeringkan sampel sedimen melayang, alat penangkap sampel menyerupai tipe US BLH-84 dengan ukuran 7,6 cm x 7,6 cm x 7,6 cm, yang pada bagian belakangnya dilengkapi dengan jaring digunakan untuk mengambil sampel sedimen dasar, dan alat ayakan yang digunakan untuk menyaring sedimen.

- Metode matematis bertujuan untuk menghitung data primer dan data sekunder untuk mencapai tujuan penelitian. Perhitungan yang digunakan dalam penelitian ini antara lain perhitungan debit aliran sungai, kadar muatan melayang, debit muatan melayang, berat jenis sedimen, dan debit muatan sedimen dasar. Pengukuran debit aliran sungai menggunakan pelampung.Lokasi pengukuran terletak pada bagian sungai yang relatif lurus dan tidak banyak pusaran air. Pengukuran kecepatan aliran dilakukan dengan cara menggerakkan suatu benda yang mengapung pada lintasan tertentu sampai dengan titik yang sudah ditentukan jaraknya (Norhadi, dkk, 2015).

Perhitungan debit aliran sungai dapat dilihat pada Persamaan 1 dan Persamaan 2.

Keterangan:

$$
\mathrm{Q}=\mathrm{A} \times \mathrm{k} \times \mathrm{V} \quad \text { (1) }
$$

$\mathrm{Q}=$ debit aliran $\left(\mathrm{m}^{3} / \mathrm{dt}\right)$

A $=$ luas penampang basah $\left(\mathrm{m}^{2}\right)$

$\mathrm{k}=$ koefisien

$\mathrm{V}=$ kecepatan pelampung $(\mathrm{m} / \mathrm{dt})$

Nilai k tergantung dari jenis pelampung yang dipakai dan dapat dihitung dengan Persamaan 2.

Keterangan:

$$
\mathrm{k}=1-0,116(\sqrt{ }(" 1-\propto ")-0,1)
$$

$\alpha=$ kedalaman tangkai (h) per kedalam air (d) yaitu kedalaman bagian pelampung yang tenggelam di bagian kedalam air.

Kadar muatan melayang dapat dilihatpada Persamaan3 (Supriyati dan Asteriqa, 2015).

$$
\mathrm{Cs}=\frac{g_{2}-g_{1}}{V}
$$

Keterangan:

Cs $=$ kadar muatan melayang $(\mathrm{mg} / \mathrm{lt})$

$\mathrm{g} 1=$ berat filter kering kosong $(\mathrm{mg})$

$\mathrm{g} 2$ = berat filter kering dan sedimen $(\mathrm{mg})$

$\mathrm{V}=$ volum air contoh melayang (lt)

Setelah diketahui kadar muatan melayang dan debit aliran, maka debit muatan sedimen melayang dapat dihitung dengan menggunakan rumus pada Persamaan 4 (Asdak, 2014).

$$
\text { Qs }=0,0864 \times \text { Cs } \times \text { Q }
$$

Keterangan:

$0,0864=$ konstanta

Qs = debit muatan sedimen melayang $(\mathrm{kg} / \mathrm{dt})$

$\mathrm{Cs}=$ kadar muatan melayang $(\mathrm{mg} / \mathrm{lt})$

$\mathrm{Q}=$ debit aliran $\left(\mathrm{m}^{3} / \mathrm{dt}\right)$

Berat jenis sedimen adalah perbandingan antara berat sedimen dengan berat air pada volum yang sama. Rumus berat jenis sedimendapat dilihat pada Persamaan 5 (Sarimai, 2017).

Dimana :

$$
\text { BJ sedimen }=\frac{(\mathrm{w} 2-\mathrm{w} 1)}{(\mathrm{w} 4-\mathrm{w} 1)-(\mathrm{w} 3-\mathrm{w} 2)}
$$

$\mathrm{W} 1=$ Piknometer kosong + tutup $(\mathrm{gr})$

$\mathrm{W} 2=$ Piknometer + tutup + sedimen $(\mathrm{gr})$

$\mathrm{W} 3$ = Piknometer + tutup + sedimen + air $($ gr $)$

$\mathrm{W} 4=$ Piknometer + tutup + air $(\mathrm{gr})$

Rumus yang digunakan untuk menghitung besarnya debit muatan sedimen dasar pada aliran sungai yaitu dengan rumus Meyer-Petter dapat dilihatpada Persamaan 6 dan Persamaan 7 (Soewarno, 1991 dalam Mokonio, dkk, 2013). 
Keterangan :

$$
\begin{gathered}
\frac{\mathrm{q}^{2 / 3}}{\mathrm{D}}-9,5\left\{\frac{\Upsilon \mathrm{s}-\Upsilon}{\Upsilon}\right\}^{10 / 9}=0,462\left\{\frac{(\Upsilon s-\Upsilon)^{1 / 3}}{\Upsilon^{1 / 3} \mathrm{D}}\right\}\left(\frac{\left({ }^{\prime}-\Upsilon\right)}{\Upsilon_{\mathrm{s}}} \mathrm{q}_{\mathrm{b}}\right)^{2 / 3} \\
\mathrm{Q}_{\mathrm{b}}=\mathrm{W} \cdot \mathrm{q}_{\mathrm{b}}
\end{gathered}
$$

$\mathrm{q}=$ Debit aliran $(\mathrm{m} 3 / \mathrm{s})$

$\mathrm{D}=$ Diameter butir sedimen $(\mathrm{mm})$

$\Upsilon=$ Berat jenis air $(\mathrm{kg} / \mathrm{m} 3)$

$\Upsilon_{\mathrm{s}} \quad=$ Berat jenis sedimen $(\mathrm{kg} / \mathrm{m} 3)$

$\mathrm{qb} \quad=$ Laju beban alas $(\mathrm{kg} /($ detik $)(\mathrm{m}))$

$\mathrm{W}=$ Lebar dasar $(\mathrm{m})$

$\mathrm{Qb} \quad=$ Berat sedimen per satuan waktu (kg/detik)

\section{HASIL DAN PEMBAHASAN}

\subsection{Morfometri Sungai Bompon}

Pola Pengaliran pada Sungai Bompon termasuk kedalam pola pengaliran dendritik. Berdasarkan jumlah/debit airnya, Sungai Bompon termasuk kedalam sungai Periodik (Intermitten), hal ini karena air yang berada di sungai tersebut dipengaruhi oleh musim. Saat musim hujan debit airnya besar, sedangkan saat musim kemarau debit airnya kecil bahkan sampai kering. Panjang sungai Bompon adalah 8,191 km dan luas Sub DAS Bompon sebesar 2,996 km², sehingga didapatkan kerapatan sungai sebesar $2,734 \mathrm{~km} / \mathrm{km}^{2}$ dimana termasuk kedalam kerapatan sedang. Penampang memanjang sungai Bompon dibagi menjadi bagian hulu, bagian tengah dan bagian hilir. Penampang memanjang sungai dari hulu ke hilir dapat dilihat pada Gambar 4. Kondisi fisik air sungai dari hulu ke hilir sungai dilihat pada Gambar 5. Penampang melintang sungai pada bagian hulu memiliki lebar saluran sungai yang kecil berukuran 1,1 m dengan bentuk seperti saluran irigasi sawah. Air sungai tersebut umumnya dimanfaatkan untuk irigasi sawah yang terletak di sepanjang sungai. Lebar penampang melintang sungai pada bagian tengah sungai sebesar $2,88 \mathrm{~m}$ dan semakin bertambah lebar menuju hilir sungai yaitu sebesar $5,73 \mathrm{~m}$. Sungai di bagian hilir tidak hanya digunakan untuk irigasi namun juga sebagai cadangan air untuk berbagai keperluan masyarakat di daerah ini, seperti kolam ikan.

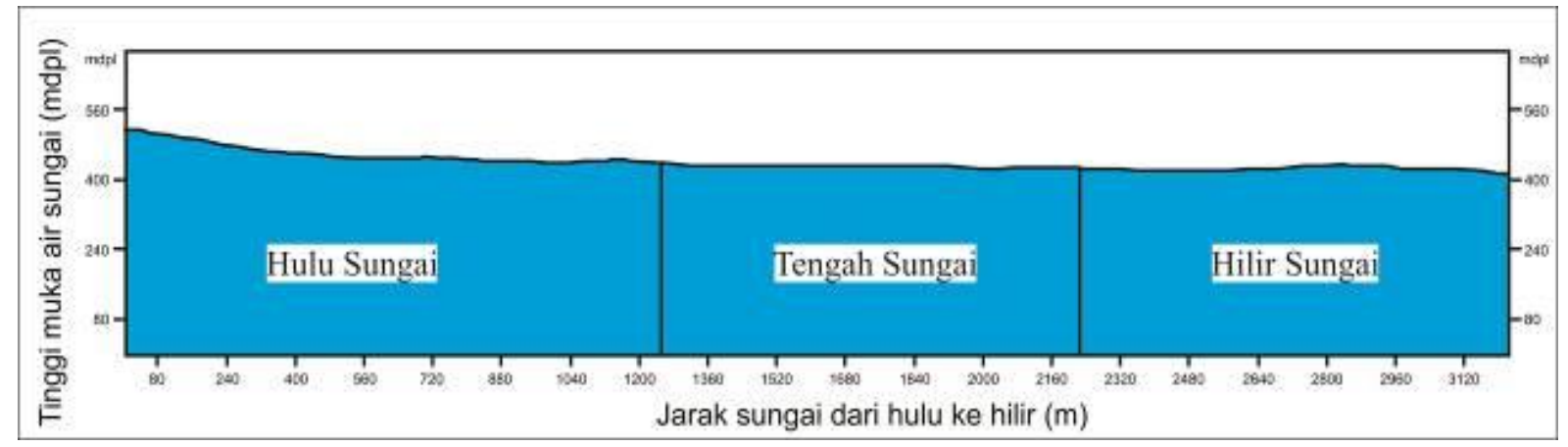

Gambar 4. Penampang Memanjang Sungai dari Hulu ke Hilir

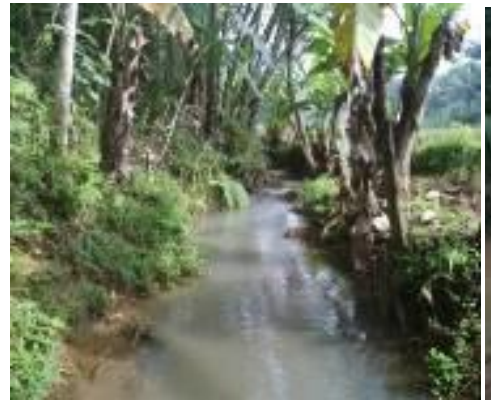

(a)

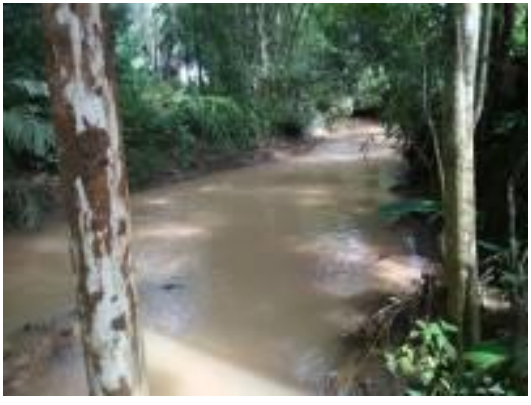

(b)

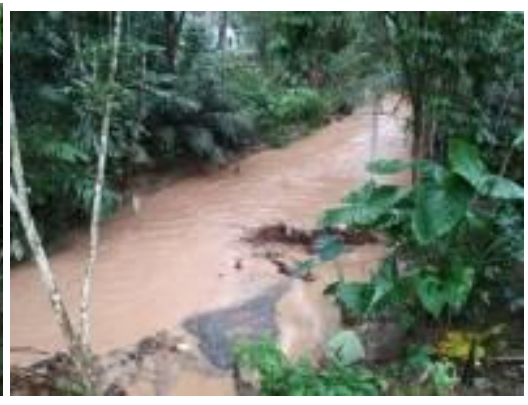

(c)

Gambar 5. (a) Sungai pada bagian Hulu; (b) Sungai pada bagian tengah; (c) Sungai pada bagian hilir; 
Bentuk penampang melintang sungai pada bagian hulu sungai Bompon memiliki kedalaman sungai yang berbeda. Bentuk penampang melintang diperoleh dari hasil pengukuran lebar dan kedalaman sungai sehingga akan di dapat luas penampang. Hasil pengukuran debit aliran pada bagian hulu sungai Bompon selama beberapa bulan dapat dilihat pada Tabel 2, dimana debit aliran rata-rata $0,023 \mathrm{~m}^{3} / \mathrm{s}$. Debit aliran sungai tertinggi sebesar $0,043 \mathrm{~m}^{3} / \mathrm{s}$ pada bulan januari/ musim hujan. Debit aliran sungai terendah sebesar $0,010 \mathrm{~m}^{3} / \mathrm{s}$ pada bulan juni/ musim kemarau. Rerata curah hujan dapat dillihat pada Tabel 1. Perbandingan penampang melintang sungai pada saat musim hujan (bulan januari) dan musim kemarau (bulan juni) bisa dilihat pada Gambar 6.

Tabel 1. Rerata Curah Hujan Sub DAS Bompon

\begin{tabular}{|c|c|c|c|c|c|c|c|c|c|c|c|c|}
\hline \multirow{3}{*}{$\begin{array}{l}\text { Bulan } \\
\text { Jan }\end{array}$} & \multicolumn{10}{|c|}{ Curah Hujan (mm) } & \multirow{2}{*}{$\begin{array}{l}\text { Jumlah } \\
\text { (mm) }\end{array}$} & \multirow{2}{*}{$\begin{array}{l}\text { Rata } \\
\text {-rata } \\
(\mathrm{m} \\
\mathrm{m} / \mathrm{th} \\
\mathrm{n})\end{array}$} \\
\hline & 2008 & 2009 & 2010 & 2011 & 2012 & 2013 & 2014 & 2015 & 2016 & 2017 & & \\
\hline & 284 & 609 & 534 & 453 & 450 & 498 & 283 & 471 & 345 & 511 & 4438 & $\begin{array}{l}443, \\
8\end{array}$ \\
\hline Feb & 368 & 426 & 371 & 344 & 269 & 414 & 405 & 329 & 363 & 451 & 3740 & 374 \\
\hline Mar & 388 & 525 & 396 & 505 & 201 & 450 & 164 & 437 & 562 & 208 & 3681 & $\begin{array}{l}368, \\
1\end{array}$ \\
\hline Apr & 371 & 287 & 232 & 343 & 289 & 410 & 343 & 394 & 205 & 328 & 3202 & $\begin{array}{l}320, \\
2\end{array}$ \\
\hline Mei & 51 & 70 & 223 & 121 & 62 & 75 & 129 & 70 & 51 & 98 & 950 & 95 \\
\hline Jun & 23 & 138 & 150 & 0 & 0 & 304 & 104 & 10 & 196 & 47 & 972 & 97,2 \\
\hline Jul & 0 & 7 & 136 & 0 & 0 & 194 & 117 & 0 & 0 & 47 & 501 & 50,1 \\
\hline $\mathrm{Agu}$ & 0 & 0 & 174 & 0 & 0 & 8 & 14 & 0 & 137 & 0 & 333 & 33,3 \\
\hline Sep & 11 & 34 & 62 & 0 & 0 & 11 & 0 & 0 & 189 & 70 & 377 & 37,7 \\
\hline Okt & 288 & 65 & 323 & 76 & 140 & 91 & 28 & 0 & 351 & 270 & 1632 & $\begin{array}{l}163, \\
2\end{array}$ \\
\hline Nov & 732 & 329 & 421 & 471 & 354 & 459 & 234 & 358 & 500 & 426 & 4284 & $\begin{array}{l}428, \\
4\end{array}$ \\
\hline Des & 192 & 227 & 292 & 485 & 462 & 418 & 603 & 472 & 419 & 382 & 3952 & $\begin{array}{l}395, \\
2\end{array}$ \\
\hline $\begin{array}{l}\text { Rata- } \\
\text { rata }\end{array}$ & $\begin{array}{l}225,6 \\
7\end{array}$ & $\begin{array}{l}226,4 \\
2\end{array}$ & $\begin{array}{l}276,1 \\
7\end{array}$ & $\begin{array}{l}2233, \\
17\end{array}$ & $\begin{array}{l}185,5 \\
8\end{array}$ & $\begin{array}{l}277,6 \\
7\end{array}$ & $\begin{array}{l}202,0 \\
0\end{array}$ & $\begin{array}{l}211, \\
75\end{array}$ & $\begin{array}{l}276 \\
50\end{array}$ & $\begin{array}{l}236 \\
50\end{array}$ & $\begin{array}{l}2351,4 \\
2\end{array}$ & $\begin{array}{l}235, \\
14\end{array}$ \\
\hline
\end{tabular}

Hasil pengukuran debit aliran pada bagian tengah sungai Bompon selama beberapa bulan dapat dilihat pada Tabel 3, dimana debit aliran rata-rata $0,130 \mathrm{~m}^{3} / \mathrm{s}$. Debit aliran sungai tertinggi sebesar $0,263 \mathrm{~m}^{3} / \mathrm{s}$ pada bulan januari/ musim hujan. Debit aliran sungai terendah sebesar $0,043 \mathrm{~m}^{3} / \mathrm{s}$ pada bulan juni/ musim kemarau. Perbandingan penampang melintang sungai saat musim hujan (bulan januari) dan musim kemarau (bulan juni) dapat dilihat pada Gambar 7.

Tabel 2. Hasil Perhitungan Debit Aliran Sungai pada bagian hulu

\begin{tabular}{lllll}
\hline Bulan & Luas Penampang $\left(\mathrm{m}^{2}\right)$ & $\mathrm{k}$ & Kecepatan aliran $(\mathrm{m} / \mathrm{s})$ & Debit Aliran $\left(\mathrm{m}^{3} / \mathrm{s}\right)$ \\
\hline Desember & 0,237 & 0,935 & 0,132 & 0,029 \\
Januari & 0,298 & 0,928 & 0,154 & 0,043 \\
Feburari & 0,274 & 0,939 & 0,139 & 0,035 \\
Maret & 0,241 & 0,932 & 0,078 & 0,018 \\
April & 0,221 & 0,934 & 0,073 & 0,015 \\
\hline
\end{tabular}




\begin{tabular}{lllll}
\hline Mei & 0,202 & 0,937 & 0,057 & 0,011 \\
\hline Juni & 0,188 & 0,929 & 0,058 & 0,010 \\
Rata-rata & & & & 0,023 \\
\hline
\end{tabular}

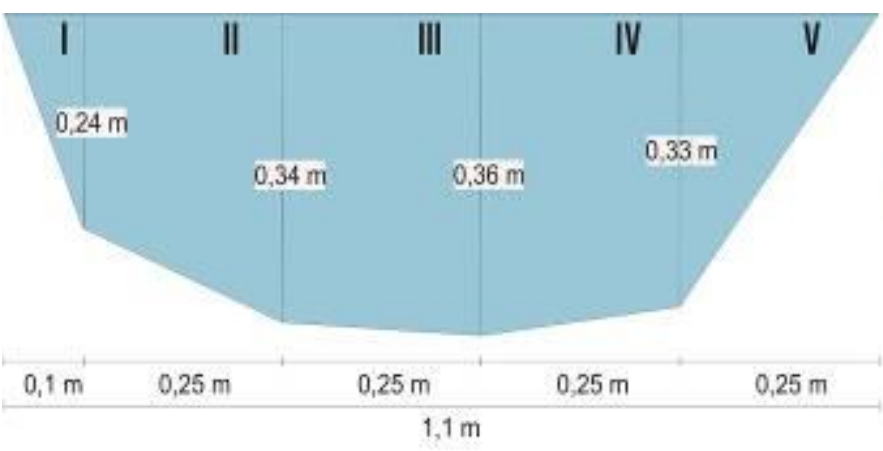

$=$ Bulan Januari Musim Hujan

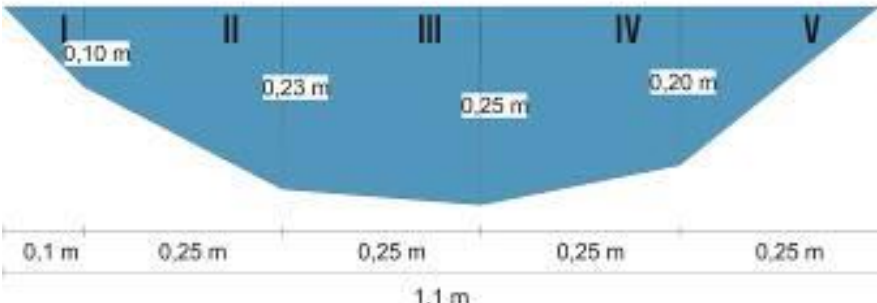

$=$ Bulan Juni/ Musim Kemarau

Gambar 6. Penampang Melintang Sungai pada Bagian Hulu berdasarkan lebar dan kedalaman sungai saat Musim Hujan \& Musim Kemarau

Tabel 3. Hasil Perhitungan Debit Aliran Sungai pada Bagian Tengah

\begin{tabular}{ccccc}
\hline Bulan & Luas Penampang $\left(\mathbf{m}^{\mathbf{2}}\right)$ & $\mathbf{k}$ & Kecepatan aliran $(\mathbf{m} / \mathbf{s})$ & Debit Aliran $\left(\mathbf{m}^{\mathbf{3}} / \mathbf{s}\right)$ \\
\hline Desember & 0,817 & 0,924 & 0,242 & 0,182 \\
Januari & 0,952 & 0,921 & 0,3 & 0,263 \\
Feburari & 0,905 & 0,923 & 0,267 & 0,223 \\
Maret & 0,641 & 0,931 & 0,111 & 0,066 \\
April & 0,676 & 0,928 & 0,113 & 0,071 \\
Mei & 0,544 & 0,931 & 0,130 & 0,066 \\
Juni & 0,369 & 0,950 & 0,123 & 0,043 \\
& \multicolumn{3}{c}{ Rata-rata } \\
\hline
\end{tabular}

Hasil pengukuran debit aliran pada bagian hilir sungai Bompon selama beberapa bulan dapat dilihat pada Tabel 4, dimana debit aliran rata-rata $0,425 \mathrm{~m}^{3} / \mathrm{s}$. Debit aliran sungai tertinggi sebesar $1,039 \mathrm{~m}^{3} / \mathrm{s}$ pada bulan Januari/ musim hujan. Debit aliran sungai terendah sebesar $0,069 \mathrm{~m}^{3} / \mathrm{s}$ pada bulan Juni/ musim kemarau. Perbandingan penampang melintang saat musim hujan (bulan Januari) dan musim kemarau (bulan Juni) bisa dilihat pada Gambar 8.

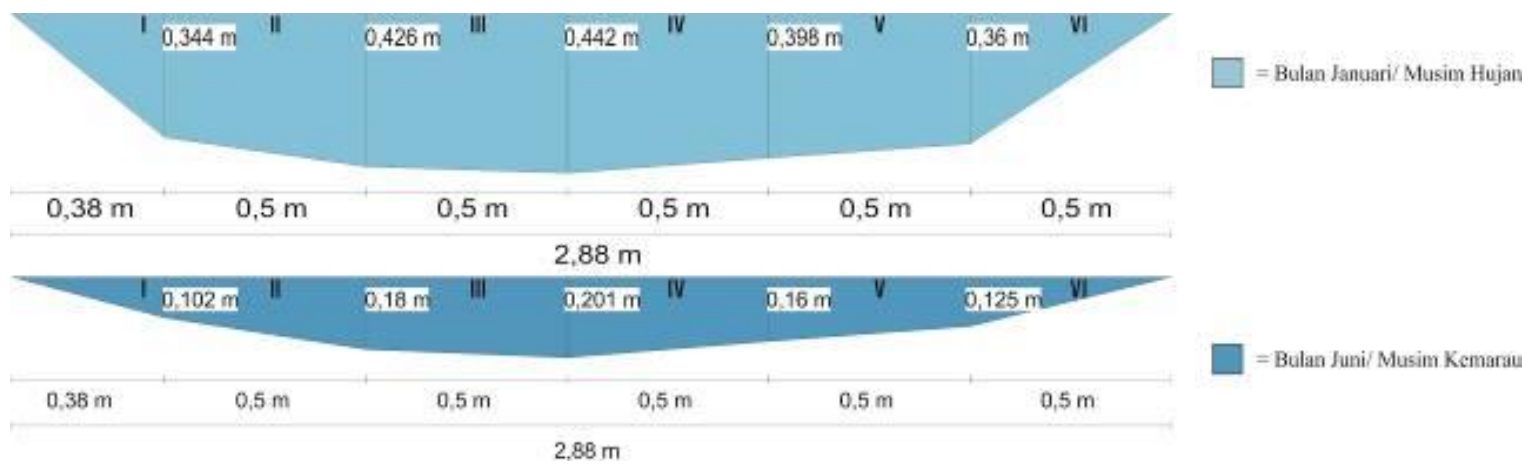

Gambar 7. Penampang Melintang Sungai pada Bagian Tengah berdasarkan lebar dan kedalaman sungai saat Musim Hujan \& Musim Kemarau

Maola Maqdan, Ekha Yogafanny, Andi Sungkowo, M. Anggri Setiawan, Junun Sartohadi 
Tabel 4. Hasil Perhitungan Debit Aliran Sungai pada Bagian Hilir

\begin{tabular}{lllll}
\hline Bulan & Luas Penampang $\left(\mathrm{m}^{2}\right)$ & $\mathrm{k}$ & Kecepatan aliran $(\mathrm{m} / \mathrm{s})$ & Debit Aliran $\left(\mathrm{m}^{3} / \mathrm{s}\right)$ \\
\hline Desember & 2,020 & 0,918 & 0,370 & 0,686 \\
Januari & 2,266 & 0,917 & 0,5 & 1,039 \\
Feburari & 2,186 & 0,917 & 0,417 & 0,836 \\
Maret & 1,294 & 0,933 & 0,111 & 0,134 \\
April & 1,499 & 0,926 & 0,088 & 0,122 \\
Mei & 1,132 & 0,936 & 0,083 & 0,088 \\
Juni & 1,039 & 0,936 & 0,071 & 0,069 \\
Rata-rata & & & & 0,425 \\
\hline
\end{tabular}

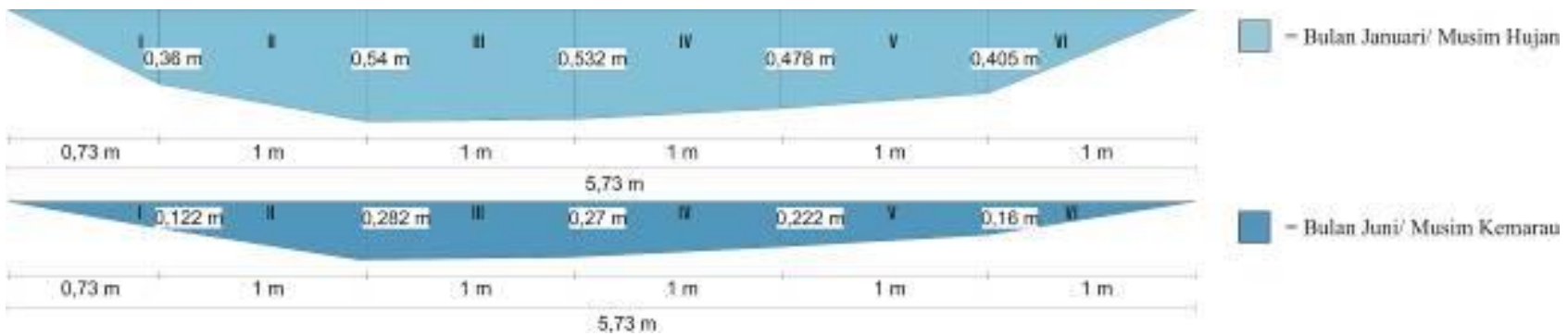

Gambar 8. Penampang Melintang Sungai pada Bagian Hilir berdasarkan lebar dan kedalaman sungai saat Musim Hujan \& Musim Kemarau

\subsection{Karakteristik Sedimen Melayang dan Sedimen Dasar bagian Hulu Sungai}

Berdasarkan hasil analisis dan perhitungan pada sampel sedimen melayang yang telah dilakukan, debit muatan sedimen melayang tertinggi sebesar 93,152 ton/tahun pada pengambilan hari ke-1 (29 Januari 2018), sedangkan debit muatan sedimen melayang terendah sebesar 25,272 ton/tahun pada pengambilan hari ke-3 (31 Januari 2018). Debit muatan sedimen melayang rata-rata pada bagian hulu sebesar 55,322 ton/tahun yang dapat dilihat pada Tabel 5.

Tabel 5. Hasil Perhitungan Debit Muatan Sedimen Melayang pada Bagian Hulu

\begin{tabular}{llllll}
\hline Tanggal & $\begin{array}{l}\text { Debit } \\
\text { Sungai } \\
\left(\mathrm{m}^{3} / \mathrm{s}\right)\end{array}$ & $\begin{array}{l}\text { Jumlah } \\
\text { Sampel }\end{array}$ & $\begin{array}{l}\text { Berat } \\
\text { Kering } \\
(\mathrm{mg})\end{array}$ & $\begin{array}{l}\text { Debit Muatan Sedimen } \\
\text { Melayang (ton/hari) }\end{array}$ & $\begin{array}{l}\text { Debit Muatan Sedimen } \\
\text { Melayang (ton/tahun) }\end{array}$ \\
\hline 29 Jan 2018 & 0,043 & 2 & 401 & 0,255 & 93,152 \\
30 Jan 2018 & 0,028 & 2 & 396 & 0,252 & 91,990 \\
& & 390 & 0,106 & 38,693 \\
31 Jan 2018 & 0,022 & 2 & 407 & 0,105 & 38,389 \\
& & 778 & 0,069 & 25,272 \\
01 Feb 2018 & 0,035 & 2 & 795 & 0,070 & 25,514 \\
& & 988 & 0,206 & 75,213 \\
02 Feb 2018 & 0,025 & 2 & 965 & 0,215 & 78,491 \\
& & 1804 & 0,120 & 43,664 \\
Rata-rata & & 1774 & 0,117 & 42,840 \\
\hline
\end{tabular}


Gambar 9 menunjukan grafik hubungan antara debit aliran dan debit muatan sedimen melayang, dirumuskan dalam bentuk Qs $=\mathrm{a} \mathrm{Q}^{\mathrm{b}}$, sehingga didapat hasil rumus dari grafik yaitu $\mathrm{Qs}=9,12119 \mathrm{Q}^{-0,12828}$ dengan $\mathrm{r}$ (korelasi) $=0,9768$. Hasil dari grafik menunjukan bahwa hubungan antara debit sungai dan debit muatan sedimen melayang mempunyai keterkaitan yang kuat.

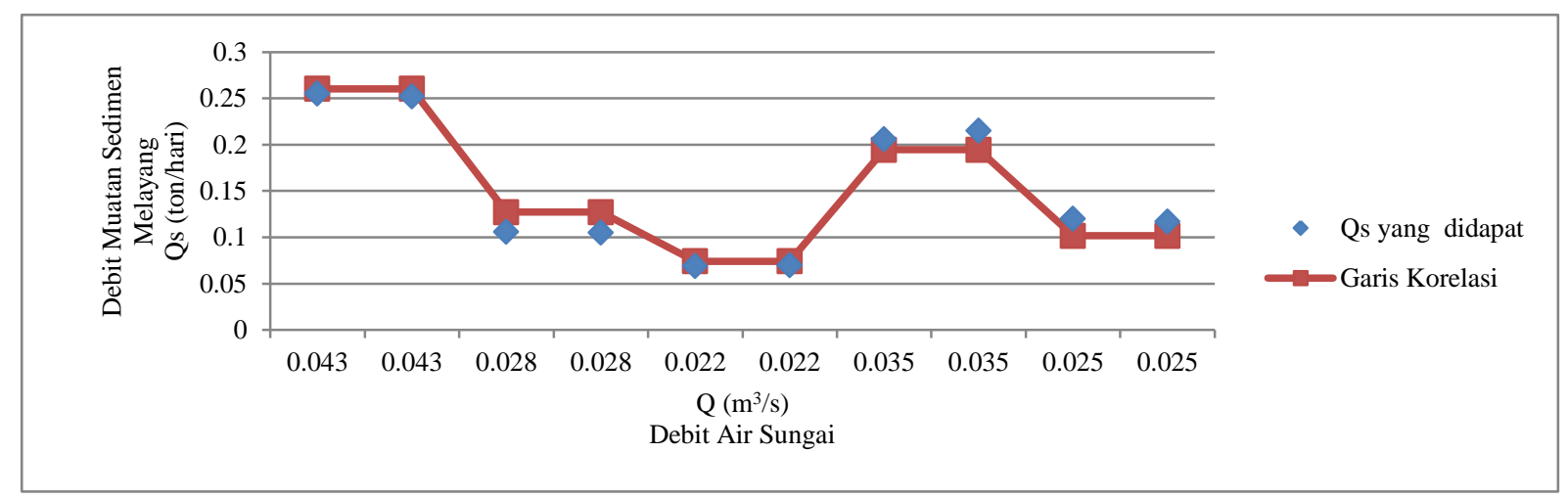

Gambar 9. Grafik Korelasi Hubungan Debit Sungai dan Debit Muatan Sedimen Melayang pada Hulu Sungai

Berdasarkan hasil analisis dan perhitungan pada sampel sedimen dasar yang telah dilakukan, debit muatan sedimen dasar tertinggi sebesar 0,592 ton/tahun pada pengambilan hari ke-1 (29 Januari 2018), sedangkan debit muatan sedimen dasar terendah sebesar 0,121 ton/tahun pada pengambilan hari ke-3 (31 Januari 2018). Debit muatan sedimen dasar yang dihasilkan memiliki rata-rata sebesar 0,323 ton/tahun yang dapat dilihat pada Tabel 6.

Tabel 6. Hasil Perhitungan Debit Muatan Sedimen Dasar pada Bagian Hulu

\begin{tabular}{|c|c|c|c|c|c|}
\hline Tanggal & $\begin{array}{l}\text { Debit } \\
\text { Sungai } \\
\left(\mathrm{m}^{3} / \mathrm{s}\right)\end{array}$ & $\begin{array}{l}\text { Diameter Butir } \\
\text { Sedimen }(\mathrm{mm})\end{array}$ & $\begin{array}{c}\text { Berat Jenis } \\
\text { Sedimen } \\
\left(\mathrm{kg} / \mathrm{m}^{3}\right)\end{array}$ & $\begin{array}{c}\text { Debit Muatan } \\
\text { Sedimen dasar } \\
\text { (ton/tahun) }\end{array}$ & $\begin{array}{c}\text { Debit Angkutan } \\
\text { Sedimen dasar } \\
\left(\mathrm{m}^{3} / \text { tahun }\right)\end{array}$ \\
\hline \multirow{2}{*}{$\begin{array}{l}29 \text { Januari } \\
2018\end{array}$} & \multirow[t]{2}{*}{0,043} & 1,680 & 2446 & 0,592 & 0,410 \\
\hline & & 1,596 & 2691 & 0,420 & 0,249 \\
\hline \multirow{2}{*}{$\begin{array}{c}30 \text { Januari } \\
2018\end{array}$} & \multirow[t]{2}{*}{0,028} & 1,253 & 2381 & 0,273 & 0,198 \\
\hline & & 0,809 & 2345 & 0,166 & 0,123 \\
\hline \multirow{2}{*}{$\begin{array}{l}31 \text { Januari } \\
2018\end{array}$} & \multirow[t]{2}{*}{0,022} & 1,550 & 2283 & 0,295 & 0,230 \\
\hline & & 0,749 & 2308 & 0,121 & 0,093 \\
\hline \multirow{2}{*}{$\begin{array}{l}\text { 01 Februari } \\
2018\end{array}$} & \multirow[t]{2}{*}{0,035} & 0,759 & 2275 & 0,216 & 0,170 \\
\hline & & 0,837 & 2381 & 0,217 & 0,157 \\
\hline \multirow{3}{*}{$\begin{array}{l}02 \text { Februari } \\
2018\end{array}$} & \multirow[t]{3}{*}{0,025} & 0,755 & 2305 & 0,142 & 0,109 \\
\hline & & 1,838 & 1925 & 0,786 & 0,850 \\
\hline & & \multicolumn{2}{|l|}{ Rata-rata } & 0,323 & 0,259 \\
\hline
\end{tabular}

Menurut Hjulstrom (1939) dalam Prasetyo, dkk (2015), diagram Hjulstrommerupakan hubungan antara kecepatan aliran air dan ukuran butir. Setelah didapatkan hasil ukuran butir, selanjutnya dicocokkan dengan diagram Hjulstrom yang bisa dilihat pada Gambar 10. Sedimen dasar pada sungai bagian hulu mempunyai ukuran butir 0,749 mm - 1,838 mm (pasir kasar - pasir sangat kasar).Berdasarkan diagram Hjulstrom, sedimen dasar pada sungai bagian hulu akan mengendap/ berhenti pada kecepatan 4,49 cm/dtk $-9,350 \mathrm{~cm} / \mathrm{dtk}$. Selain itu sedimen dasar pada bagian hulu ini akan menggerakkan/ mengerosi partikel dari kondisi diam pada kecepatan $31,633 \mathrm{~cm} / \mathrm{dtk}-48,376 \mathrm{~cm} / \mathrm{dtk}$. Hal ini dikarenakan ukuran butir sedimen pasir kasar dan pasir sangat kasar maka kecepatan aliran yang dibutuhkan juga besar untuk mengangkut butiran sedimen dasar tersebut. Kecepatan aliran yang tinggi dapat mengerosi/menggerakkan sedimen dasar yang berada pada bagian hulu sungai, hal ini menandakan bahwa semakin besar ukuran butir maka akan semakin besar pula kecepatan aliran yang dibutuhkan untuk mengerosi material dengan tersebut. 


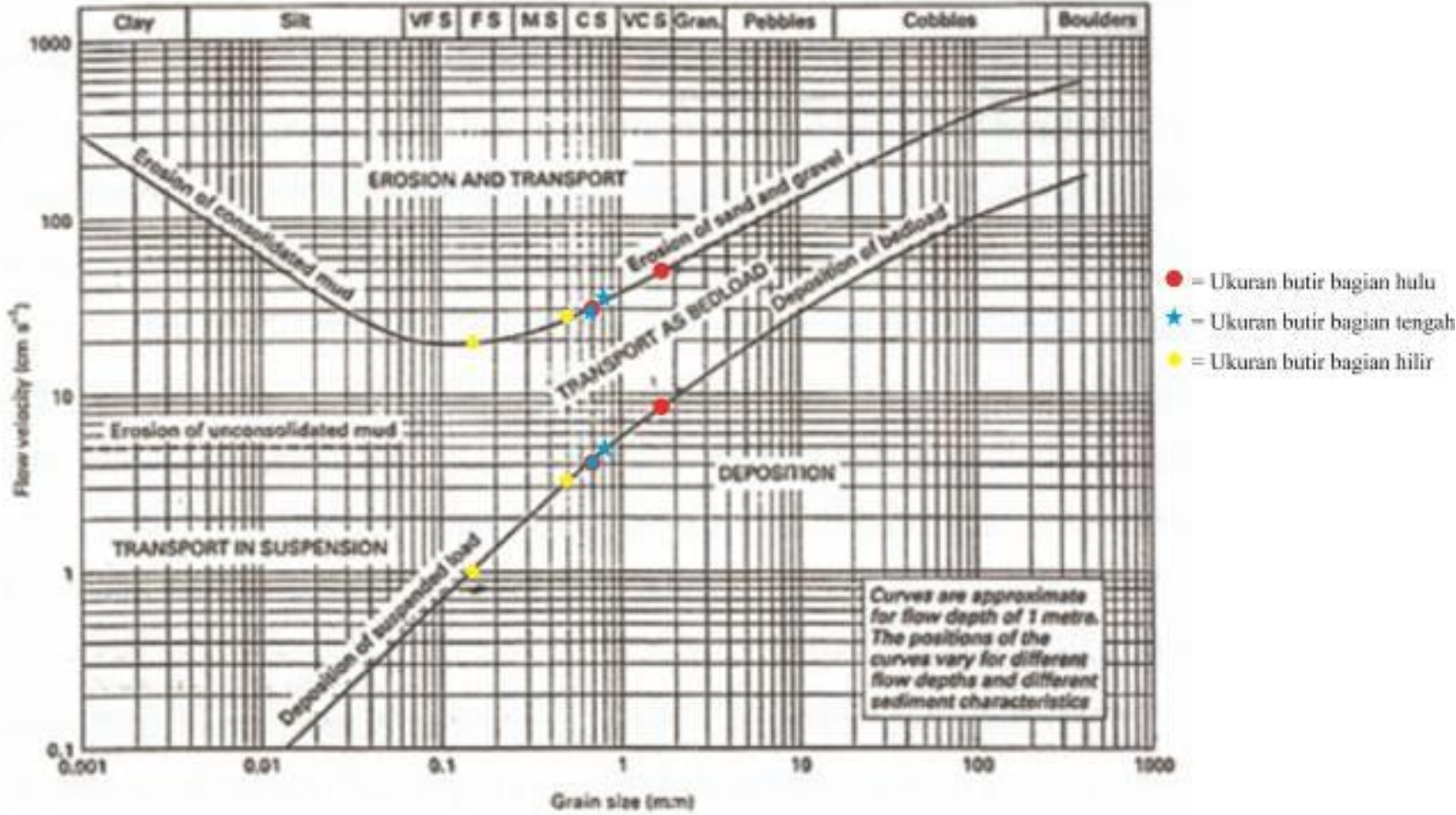

Gambar 10. Distribusi Ukuran Butir Sedimen Dasar pada Sungai Bagian Hulu hingga Hilir

Sumber: Prasetyo, dkk (2015)

\subsection{Karakteristik Sedimen Melayang dan Sedimen Dasar bagian Tengah Sungai}

Berdasarkan hasil analisis dan perhitungan pada sampel sedimen melayang yang telah dilakukan, debit muatan sedimen melayang tertinggi sebesar 1837,106 ton/tahun pada pengambilan hari ke-1 (29 Januari 2018), sedangkan debit muatan sedimen melayang terendah sebesar 278,244 ton/tahun pada pengambilan hari ke-3 (31 Januari 2018). Debit muatan sedimen melayang yang dihasilkan memiliki rata-rata sebesar 945,570 ton/tahun yang dapat dilihat pada Tabel 7.

Tabel 7. Hasil Perhitungan Debit Muatan Sedimen Melayang pada Bagian Tengah

\begin{tabular}{llllll}
\hline Tanggal & $\begin{array}{l}\text { Debit } \\
\text { Sungai } \\
\left(\mathrm{m}^{3} / \mathrm{s}\right)\end{array}$ & $\begin{array}{l}\text { Jumlah } \\
\text { Sampel }\end{array}$ & $\begin{array}{l}\text { Berat } \\
\text { Kering } \\
(\mathrm{mg})\end{array}$ & $\begin{array}{l}\text { Debit Muatan Sedimen } \\
\text { Melayang (ton/hari) }\end{array}$ & $\begin{array}{l}\text { Debit } \\
\text { Sedimen } \\
\text { (ton/tahun) }\end{array}$ \\
\hline 29 Jan 2018 & 0,263 & 2 & 254 & 5,033 & $\begin{array}{r}\text { Muatan } \\
\text { Melayang }\end{array}$ \\
30 Jan 2018 & 0,088 & 2 & 252 & 4,762 & 1738,229 \\
& & 318 & 1,018 & 371,552 \\
31 Jan 2018 & 0,077 & 2 & 312 & 1,040 & 379,671 \\
& & & 666 & 0,762 & 278,244 \\
01 Feb 2018 & 0,223 & 2 & 721 & 0,825 & 301,223 \\
& & 2328 & 5,035 & 1837,675 \\
02 Feb 2018 & 0,083 & 2 & 2406 & 5,011 & 1829,178 \\
& & 2910 & 1,224 & 446,609 \\
Rata-rata & & 3016 & 1,195 & 436,212 \\
\hline
\end{tabular}

Gambar 11 menunjukan grafik hubungan antara debit aliran dan debit muatan sedimen melayang, dirumuskan dalam bentuk Qs $=\mathrm{a} \mathrm{Q}^{\mathrm{b}}$, sehingga didapat hasil rumus dari grafik yaitu $\mathrm{Qs}=23,9113 \mathrm{Q}^{-0,58204}$ dengan $\mathrm{r}$ (korelasi) 
$=0,98178$. Hasil dari grafik diatas menunjukan bahwa hubungan antara debit sungai dan debit muatan sedimen melayang mempunyai keterkaitan yang kuat.

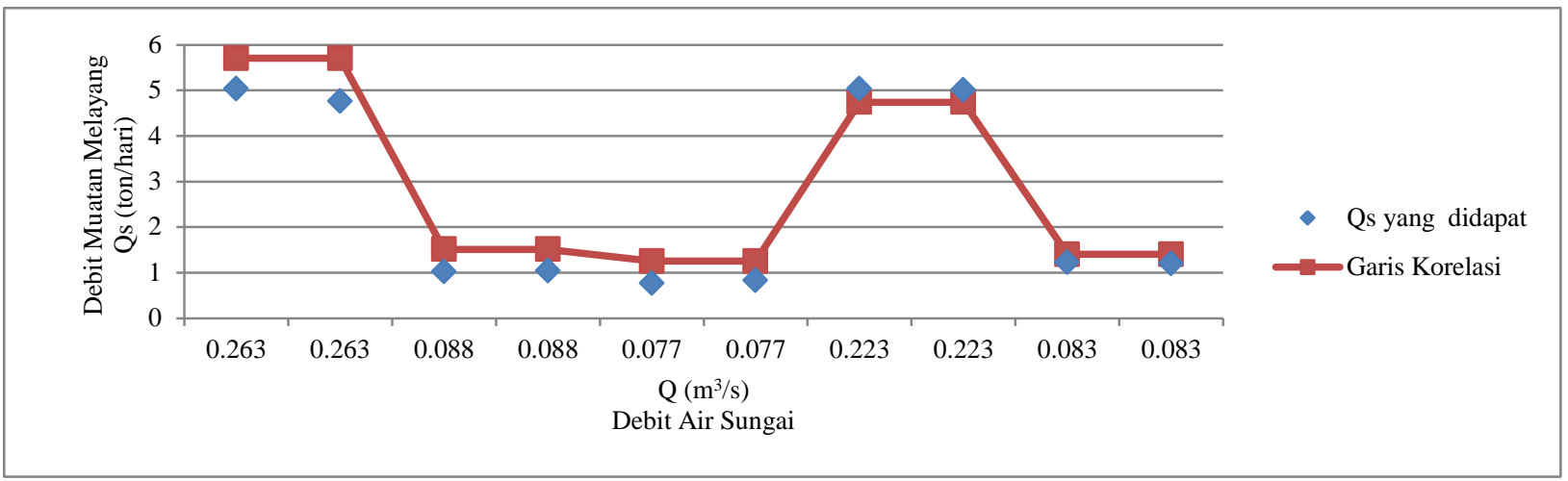

Gambar 11. Grafik Korelasi Hubungan Debit Sungai dan Debit Muatan Sedimen Melayang pada Tengah Sungai

Berdasarkan hasil analisis dan perhitungan pada sampel sedimen dasar yang telah dilakukan, debit muatan sedimen dasar tertinggi sebesar 4,731 ton/tahun pada pengambilan hari ke-1 (29 Januari 2018), sedangkan debit muatan sedimen dasar terendah sebesar 0,876 ton/tahun pada pengambilan hari ke-3 (31 Januari 2018). Debit muatan sedimen dasar yang dihasilkan memiliki rata-rata sebesar 2,077 ton/tahun yang dapat dilihat pada Tabel 8.

Tabel 8. Hasil Perhitungan Debit Muatan Sedimen Dasar pada Bagian Tengah

\begin{tabular}{|c|c|c|c|c|c|c|}
\hline Tanggal & $\begin{array}{l}\text { Debit } \\
\text { Sungai } \\
\left(\mathrm{m}^{3} / \mathrm{s}\right)\end{array}$ & $\begin{array}{l}\text { Diameter Butir } \\
\text { Sedimen }(\mathrm{mm})\end{array}$ & $\begin{array}{ll}\text { Berat } & \text { Jenis } \\
\text { Sedimen } & \\
\left(\mathrm{kg} / \mathrm{m}^{3}\right) & \end{array}$ & $\begin{array}{l}\text { Debit } \\
\text { Sedimen } \\
\text { (ton/tahun) }\end{array}$ & $\begin{array}{r}\text { Muatan } \\
\text { dasar }\end{array}$ & $\begin{array}{l}\text { Debit Angkutan } \\
\text { Sedimen dasan } \\
\left(\mathrm{m}^{3} / \text { tahun }\right)\end{array}$ \\
\hline \multirow{2}{*}{$\begin{array}{l}29 \text { Januari } \\
2018\end{array}$} & \multirow[t]{2}{*}{0,263} & 0,759 & 2279 & 4,731 & & 3,699 \\
\hline & & 0,727 & 2356 & 4,076 & & 3,006 \\
\hline \multirow{2}{*}{$\begin{array}{l}30 \text { Januari } \\
2018\end{array}$} & \multirow{2}{*}{0,088} & 0,771 & 2777 & 0,946 & & 0,532 \\
\hline & & 0,783 & 2433 & 1,334 & & 0,931 \\
\hline \multirow{2}{*}{$\begin{array}{l}31 \text { Januari } \\
2018\end{array}$} & \multirow[t]{2}{*}{0,077} & 0,751 & 2658 & 0,876 & & 0,528 \\
\hline & & 0,817 & 2477 & 1,173 & & 0,794 \\
\hline \multirow{2}{*}{$\begin{array}{l}01 \text { Februari } \\
2018\end{array}$} & \multirow[t]{2}{*}{0,223} & 0,785 & 2552 & 3,156 & & 2,034 \\
\hline & & 0,769 & 3027 & 2,093 & & 1,033 \\
\hline \multirow{2}{*}{$\begin{array}{l}\text { 02 Februari } \\
2018\end{array}$} & \multirow[t]{2}{*}{0,083} & 0,763 & 2499 & 1,134 & & 0,756 \\
\hline & & 0,727 & 2343 & 1,250 & & 0,931 \\
\hline Rata-rata & & & & 2,077 & & 1,424 \\
\hline
\end{tabular}

Setelah didapatkan hasil ukuran butir, selanjutnya dicocokkan dengan diagram Hjulstrom yang bisa dilihat pada Gambar 10.Sungai tengah mempunyai ukuran butir $0,727 \mathrm{~mm}-0,817 \mathrm{~mm}$ (pasir kasar). Berdasarkan diagram Hjulstrom, sedimen dasar pada sungai bagian tengah akan mengendap/ berhenti pada kecepatan 4,27 cm/dtk $5,0085 \mathrm{~cm} / \mathrm{dtk}$. Selain itu sedimen dasar pada bagian tengah ini akan menggerakkan/ mengerosi partikel dari kondisi diam pada kecepatan 30,9 cm/dtk - 33,9 cm/dtk. Hal ini dikarenakan ukuran butir sedimen pasir kasar maka kecepatan aliran yang dibutuhkan juga cukup besar untuk mengangkut butiran sedimen dasar tersebut dibandingkan pada bagian hulu sungai. Kecepatan aliran yang cukup tinggi untuk mengerosi/menggerakkan sedimen dasar yang berada pada bagian tengah sungai, hal ini menandakan bahwa semakin besar ukuran butir maka akan semakin besar pula kecepatan aliran yang dibutuhkan untuk mengerosi material dengan ukuran tersebut. 


\subsection{Karakteristik Sedimen Melayang dan Sedimen Dasar bagian Hilir Sungai}

Berdasarkan hasil analisis dan perhitungan pada sampel sedimen melayang yang telah dilakukan, debit muatan sedimen melayang tertinggi sebesar 13619,817 ton/tahun pada pengambilan hari ke-1 (29 Januari 2018), sedangkan debit muatan sedimen melayang terendah sebesar 4064,490ton/tahun pada pengambilan hari ke-5 (02 Februari 2018). Debit muatan sedimen melayang yang dihasilkan memiliki rata-rata sebesar 8297,002ton/tahun yang dapat dilihat pada Tabel 9.

Tabel 9. Hasil Perhitungan Debit Muatan Sedimen Melayang pada Bagian Hilir

\begin{tabular}{|c|c|c|c|c|c|}
\hline Tanggal & $\begin{array}{l}\text { Debit Sungai } \\
\left(\mathrm{m}^{3} / \mathrm{s}\right)\end{array}$ & $\begin{array}{l}\text { Jumlah } \\
\text { Sampel }\end{array}$ & $\begin{array}{l}\text { Berat } \\
\text { Kering (mg) }\end{array}$ & $\begin{array}{l}\text { Debit Muatan Sedimen } \\
\text { Melayang (ton/hari) }\end{array}$ & $\begin{array}{l}\text { Debit Muatan Sedimen } \\
\text { Melayang (ton/tahun) }\end{array}$ \\
\hline \multirow{2}{*}{$\begin{array}{l}29 \text { Januari } \\
2018\end{array}$} & \multirow{2}{*}{1,039} & \multirow[t]{2}{*}{2} & 209 & 36,105 & 13178,276 \\
\hline & & & 211 & 37,315 & 13619,817 \\
\hline \multirow{2}{*}{$\begin{array}{l}30 \text { Januari } \\
2018\end{array}$} & \multirow[t]{2}{*}{0,571} & \multirow[t]{2}{*}{2} & 1282 & 16,985 & 6199,626 \\
\hline & & & 1213 & 17,369 & 6339,678 \\
\hline \multirow{2}{*}{$\begin{array}{l}31 \text { Januari } \\
2018\end{array}$} & \multirow[t]{2}{*}{0,436} & \multirow[t]{2}{*}{2} & 1514 & 11,740 & 4285,123 \\
\hline & & & 1507 & 11,545 & 4213,863 \\
\hline \multirow{2}{*}{$\begin{array}{l}01 \text { Februari } \\
2018\end{array}$} & \multirow[t]{2}{*}{0,836} & \multirow[t]{2}{*}{2} & 1992 & 36,305 & 13251,467 \\
\hline & & & 2037 & 37,628 & 13734,167 \\
\hline \multirow{2}{*}{$\begin{array}{l}02 \text { Februari } \\
2018\end{array}$} & \multirow[t]{2}{*}{0,317} & \multirow[t]{2}{*}{2} & 2351 & 11,136 & 4064,490 \\
\hline & & & 2362 & 11,188 & 4083,508 \\
\hline Rata-rata & & & & & 8297,002 \\
\hline
\end{tabular}

Gambar 12 menunjukan grafik hubungan antara debit aliran dan debit muatan sedimen melayang, dirumuskan dalam bentuk $\mathrm{Qs}=\mathrm{a} \mathrm{Q}^{\mathrm{b}}$, sehingga didapat hasil rumus dari grafik yaitu $\mathrm{Qs}=42,3715 \mathrm{Q}^{-1,14840}$ dengan $\mathrm{r}$ (korelasi) $=0,95373$. Hasil dari grafik diatas menunjukan bahwa hubungan antara debit sungai dan debit muatan sedimen melayang mempunyai keterkaitan yang kuat.

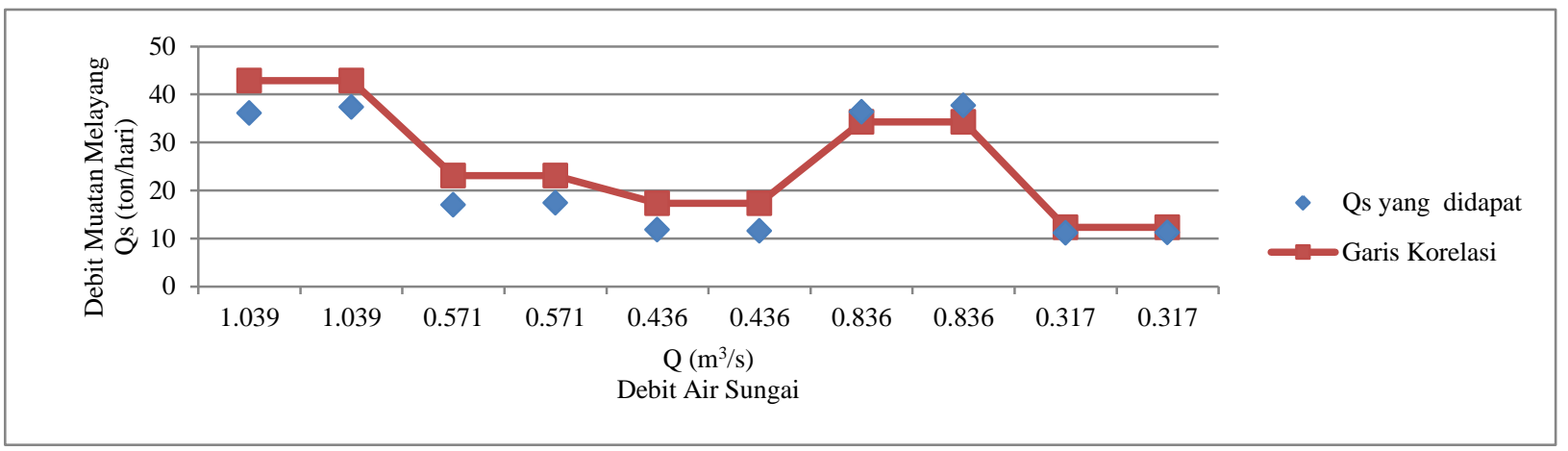

Gambar 12. Grafik Korelasi Hubungan Debit Sungai dan Debit Muatan Sedimen Melayang pada Hilir Sungai

Berdasarkan hasil analisis dan perhitungan pada sampel sedimen dasar yang telah dilakukan, debit muatan sedimen dasar tertinggi sebesar 10,405 ton/tahun pada pengambilan hari ke-4 (01 Februari 2018), sedangkan debit muatan sedimen dasar terendah sebesar 0,894 ton/tahun pada pengambilan hari ke-3 (31 Januari 2018). Debit muatan sedimen dasar yang dihasilkan memiliki rata-rata sebesar 5,975 ton/tahun yang dapat dilihat pada Tabel 10. 
Tabel 10. Hasil Perhitungan Debit Muatan Sedimen Dasar pada Bagian Hilir

\begin{tabular}{|c|c|c|c|c|c|c|}
\hline Tanggal & $\begin{array}{l}\text { Debit } \\
\text { Sungai } \\
\left(\mathrm{m}^{3} / \mathrm{s}\right)\end{array}$ & $\begin{array}{l}\text { Diameter Butir } \\
\text { Sedimen }(\mathrm{mm})\end{array}$ & $\begin{array}{ll}\text { Berat } & \text { Jenis } \\
\text { Sedimen } & \\
\left(\mathrm{kg} / \mathrm{m}^{3}\right) & \end{array}$ & $\begin{array}{l}\text { Debit } \\
\text { Sedimen } \\
\text { (ton/tahun) }\end{array}$ & $\begin{array}{r}\text { Muatan } \\
\text { dasar }\end{array}$ & $\begin{array}{l}\text { Debit Angkutan } \\
\text { Sedimen dasar } \\
\left(\mathrm{m}^{3} / \text { tahun }\right)\end{array}$ \\
\hline \multirow[t]{2}{*}{29 Jan 2018} & 1,039 & 0,380 & 3546 & 5,308 & & 2,085 \\
\hline & & 0,397 & 2987 & 7,871 & & 3,961 \\
\hline \multirow[t]{2}{*}{30 Jan 2018} & 0,571 & 0,375 & 2181 & 8,230 & & 6,969 \\
\hline & & 0,514 & 3648 & 4,297 & & 1,623 \\
\hline \multirow[t]{2}{*}{31 Jan 2018} & 0,436 & 0,513 & 2434 & 7,527 & & 5,249 \\
\hline & & 0,184 & 3235 & 0,894 & & 0,400 \\
\hline \multirow[t]{2}{*}{01 Feb 2018} & 0,836 & 0,370 & 2913 & 5,995 & & 3,134 \\
\hline & & 0,509 & 2805 & 10,405 & & 5,764 \\
\hline \multirow[t]{2}{*}{02 Feb 2018} & 0,317 & 0,546 & 2666 & 4,825 & & 2,896 \\
\hline & & 0,524 & 2706 & 4,395 & & 2,576 \\
\hline Rata-rata & & & & 5,975 & & 3,466 \\
\hline
\end{tabular}

Setelah didapatkan hasil ukuran butir, selanjutnya dicocokkan dengan diagram Hjulstrom yang bisa dilihat pada Gambar 10. Sungai hilir mempunyai ukuran butir $0,184 \mathrm{~mm}-0,546 \mathrm{~mm}$ (pasir halus - pasir kasar). Berdasarkan diagram Hjulstrom, sedimen dasar pada sungai bagian hulu akan mengendap/ berhenti pada kecepatan $1,248 \mathrm{~cm} / \mathrm{dtk}-3,229 \mathrm{~cm} / \mathrm{dtk}$. Selain itu sedimen dasar pada bagian hulu ini akan menggerakkan/ mengerosi partikel dari kondisi diam pada kecepatan $20 \mathrm{~cm} / \mathrm{dtk}-26,916 \mathrm{~cm} / \mathrm{dtk}$. Hal ini dikarenakanukuran butir sedimen pasir halus sampai pasir kasar maka kecepatan aliran yang dibutuhkan kecil hingga lumayan besar untuk mengangkut butiran sedimen tersebut dibandingkan pada bagian hulu sungai.Kecepatan aliran yang dibutuhkankecil hingga cukup tinggiuntuk mengerosi/menggerakkan sedimen dasar yang berada pada bagian hilir sungai, hal ini menandakan bahwa semakin besar ukuran butir maka akan semakin besar pula kecepatan aliran yang dibutuhkan untuk mengerosi material dengan ukuran tersebut.

Banyak faktor yang mempengaruhi nilai debit muatan sedimen diantaranya adalah debit aliran sungai. Pada sungai bagian hilir dan sungai bagian hulu, sungai hilir memiliki lebar sebesar 5,73 m, dan debit aliran sungai terendah sebesar $0,317 \mathrm{~m}^{3} / \mathrm{s}$ sedangkan sungai hulu memiliki lebar sungai sebesar $1,1 \mathrm{~m}$ dan debit aliran sungai sebesar $0,01 \mathrm{~m}^{3} / \mathrm{s}$. Faktor selanjutnya yaitu hujan. Adanya hujan akan membuat debit aliran sungai semakin besar, sehingga akan berdampak pula pada nilai debit muatan sedimen yang semakin besar.

Selain itu adanya hujan/ tidak hujan saat pengambilan sampel mempengaruhi nilai debit muatan sedimen tersebut. Pengambilan sampel hari ke-1 dan hari ke-4 mempunyai debit muatan sedimen yang lebih besar dari pengambilan sampel hari yang lainnya. Hal ini dikarenakan saat pengambilan sampel hari ke-1 dan hari ke-4 terjadi hujan sehingga menyebabkan debit muatan sedimen tinggi. Hari lainya mengalami penurunan debit muatan sedimen hal tersebut dikarenakan intesitas curah hujan tidak terlalu tinggi/ tidak terjadi hujan saat pengambilan sampel.

Erosi pada permukaan sangat dipengaruhi oleh hujan sebagai input aliran permukaan tersebut. Peningkatan hujan menyebabkan terjadinya peningkatan aliran permukaan yang selanjutnya akan menyebabkan peningkatan erosi. Hasil dari proses erosi aliran permukaan selanjutnya terangkut sebagai muatan melayang pada saluran sungai. Hal tersebut menandakan terjadinya kehilangan tanah maupun material lainnya yang disebabkan oleh erosi yang dipengaruhi oleh besarnya aliran permukaan. Erosi yang terjadi pada saat kejadian hujan dapat memperbesar nilai debit muatan sedimen. Semakin besar intensitas hujan dan kecepatan jatuh air hujan berdampak pada kekuatan tumbukan butir air hujan pada tanah yang semakin kuat mendispersi tanah sehingga menghasilkan aliran permukaan dan debit aliran yang besar. Tanah yang terkikis tersebut maka akan memungkinkan aliran permukaan untuk membawa material lepas tersebut ke dalam sungai. Faktor selanjutnya yaitu faktor kondisi kemiringan lereng. Dengan adanya kemiringan lereng yang agak curam dan miring yang mendominasi pada daerah penelitian maka akan memudahkan aliran permukaan dengan cepat menuju ke badan sungai. 


\section{KESIMPULAN DAN SARAN}

1. Karakteristik sedimen melayang dan sedimen dasar pada bagian hulu Sungai Bompon adalah sebagai berikut.

- Debit aliran sungai berkisar antara $0,010 \mathrm{~m}^{3} / \mathrm{s}$ hingga $0,043 \mathrm{~m}^{3} / \mathrm{s}$ dengan debit aliran sungai rata-rata $0,023 \mathrm{~m}^{3} / \mathrm{s}$. Debit aliran sungai tertinggi sebesar $0,043 \mathrm{~m}^{3} / \mathrm{s}$ pada bulan januari/ musim hujan. Debit aliran sungai terendah sebesar $0,010 \mathrm{~m}^{3} / \mathrm{s}$ pada bulan juni/ musim kemarau.

- Debit muatan sedimen melayang tertinggi sebesar 93,152 ton/tahun pada pengambilan hari ke-1 (29 Januari 2018). Debit muatan sedimen melayang terendah sebesar 25,272 ton/tahun pada pengambilan hari ke-3 (31 Januari 2018). Debit muatan sedimen melayang yang dihasilkan memiliki rata-rata sebesar 55,322 ton/tahun dengan kisaran debit muatan sedimen melayang antara 25,272 ton/tahun sampai 93,152 ton/tahun.

- Debit muatan sedimen dasar tertinggi sebesar 0,592 ton/tahun pada pengambilan hari ke-1 (29 Januari 2018). Debit muatan sedimen dasar terendah sebesar 0,121 ton/tahun pada pengambilan hari ke-3 (31 Januari 2018). Debit muatan sedimen dasar yang dihasilkan memiliki rata-rata sebesar 0,323 ton/tahun dengan kisaran debit muatan sedimen dasar antara 0,121 ton/tahun sampai 0,592 ton/tahun.

2. Karakteristik sedimen melayang dan sedimen dasar pada bagian tengah Sungai Bompon adalah sebagai berikut.

- Debit aliran sungai berkisar antara $0,043 \mathrm{~m}^{3} / \mathrm{s}$ hingga $0,263 \mathrm{~m}^{3} / \mathrm{s}$ dengan debit aliran sungai rata-rata $0,130 \mathrm{~m}^{3} / \mathrm{s}$. Debit aliran sungai tertinggi sebesar $0,263 \mathrm{~m}^{3} / \mathrm{s}$ pada bulan januari/ musim hujan. Debit aliran sungai terendah sebesar $0,043 \mathrm{~m}^{3} / \mathrm{s}$ pada bulan juni/ musim kemarau.

- Debit muatan sedimen melayang tertinggi sebesar 1837,106 ton/tahun pada pengambilan hari ke-1 (29 Januari 2018). Debit muatan sedimen melayang terendah sebesar 278,244 ton/tahun pada pengambilan hari ke-3 (31 Januari 2018). Debit muatan sedimen melayang yang dihasilkan memiliki rata-rata sebesar 945,570 ton/tahun dengan kisaran debit muatan sedimen melayang antara 278,244 ton/tahun sampai 1837,106 ton/tahun.

- Debit muatan sedimen dasar tertinggi sebesar 4,731 ton/tahun pada pengambilan hari ke-1 (29 Januari 2018). Debit muatan sedimen dasar terendah sebesar 0,876 ton/tahun pada pengambilan hari ke-3 (31 Januari 2018). Debit muatan sedimen dasar yang dihasilkan memiliki rata-rata sebesar 2,077 ton/tahun dengan kisaran debit muatan sedimen dasar antara 0,876 ton/tahun sampai 4,731 ton/tahun.

3. Karakteristik sedimen melayang dan sedimen dasar pada bagian hilir Sungai Bompon adalah sebagai berikut.

- Debit aliran sungai berkisar antara $0,069 \mathrm{~m}^{3} / \mathrm{s}$ hingga $1,039 \mathrm{~m}^{3} / \mathrm{s}$ dengan debit aliran sungai rata-rata $0,425 \mathrm{~m}^{3} / \mathrm{s}$. Debit aliran sungai tertinggi sebesar $1,039 \mathrm{~m}^{3} / \mathrm{s}$ pada bulan januari/ musim hujan. Debit aliran sungai terendah sebesar $0,069 \mathrm{~m}^{3} / \mathrm{s}$ pada bulan juni/ musim kemarau.

- Debit muatan sedimen melayang tertinggi sebesar 13619,817 ton/tahun pada pengambilan hari ke-1 (29 Januari 2018). Debit muatan sedimen melayang terendah sebesar 4064,490 ton/tahun pada pengambilan hari ke-5 (02 Februari 2018). Debit muatan sedimen melayang yang dihasilkan memiliki rata-rata sebesar 8297,002 ton/tahun dengan kisaran debit muatan sedimen melayang antara 4064,490 ton/tahun sampai 13619,817 ton/tahun.

- Debit muatan sedimen dasar tertinggi sebesar 10,405 ton/tahun pada pengambilan hari ke-4 (01 Februari 2018). Debit muatan sedimen dasar terendah sebesar 0,894 ton/tahun pada pengambilan hari ke-3 (31 Januari 2018). Debit muatan sedimen dasar yang dihasilkan memiliki rata-rata sebesar 5,975 SARAN ton/tahun dengan kisaran debit muatan sedimen dasar antara 0,894 ton/tahun sampai 10,405 ton/tahun.

1) Warga sekitar hendaknya mengelola dan konservasi lahan pertanian, penerapan teknik penutupan lahan dengan tanaman, pemeliharaan tebing sungai dan melakukan pembangunan disekitar sungai dengan ekohidraulik ataupun hidraulik.

2) Hendaknya masyarkat mengelola dan menjaga kuantitas dan kualitas sungai, serta menjaga hubungan yang harmonis antar warga yang berada pada Sub DAS Bompon.

3) Pemerintahan yang terlibat membantu dan memfasilitasi yang dibutuhkan warga guna menjaga kelestarian sungai dari segi kualitas dan kuantitas sungai. Serta melakukan pemantauan dan meminta warga membuat laporan agar catatan pemantauan masih ada, agar tidak terjadi kesalahan teknis.

\section{UCAPAN TERIMA KASIH}

Ucapan terimakasih sebesar-besarnya penulis sampaikan kepada Laboratorium Transbulent Universitas Gadjah Mada beserta Kepala Dusun dan masyarakat di Sub DAS Bompon, Kabupaten Magelang, Jawa Tengah atas segala bantuan, ilmu, dan partisipasinya sehingga penelitian ini dapat selesai dengan baik. 


\section{DAFTAR PUSTAKA}

Asdak, Chay. (2014). Hidrologi dan pengelolaan daerah aliran sungai. Cetakan keenam. Yogyakarta: Gajah Mada University Press.

Effendi, H.. (2003). Telaah kualitas air bagi pengelolaan sumber daya dan lingkungan perairan. Cetakan kelima. Yogyakarta: PT Kanisius.

Febiansyah, Dharma, Mudjiatko dan Trimaijon.( 2018). Analisis potensi erosi DAS Sungai Merbau dan DAS Sungai Ukui terhadap sedimentasi Danau Kayangan. Jurnal JOM FTEKNIK, Vol. 5, No. 1 April 2018

Martini, Endri, Hesti Lestari Tata, Elok Mulyoutami, Jusupta Tarigan dan Subekti Rahayu. (2010). Membangun kebun campuran belajar dari Kobun Pocal di Tapanuli dan Lampoeh di Tripa. World Agroforestry Centre (ICRAF). Bogor.

Mokonio, Olviana, T. Mananoma, L. Tanudjaja dan A. Binilang. (2013). Analisis sedimentasi di Muara Sungai Saluwangko di Desa Tounelet Kecamatan Kakas Kabupaten Minahasa. Jurnal Sipil Statik Universitas Sam Ratulangi, Manado, Vol. 1, No. 6, Mei 2013 (452-458), ISSN: 2337-6732.

Norhadi, Ahmad, Akhmad Marzuki, Luki Wicaksono dan Rendi Addetya Yacob. (2015). Studi Debit Aliran pada Sungai Antasan Kelurahan Sungai Andai Banjarmasin Utara. Jurnal POROS TEKNIK, Vol. 7, No.1, Juni 2015 (1-53), ISSN 2442-7764.

Prasetyo, Dani, Very Dermawan dan Andre Primantyo H.. 2015. Kajian penanganan sedimenasi Sungai Banjir Kanal Barat Kota Semarang. Jurnal Teknik Pengairan, Vol 6, No 1 (2015).76-87.

Rokhmaningtyas, Rusma Prima dan Muhammad Anggri Setiawan. (2017). Estimasi kehilangan tanah aktual terkait pengaruh vegetasi di DAS Bompon Kabupaten Magelang. Jurnal Geografi UGM. Yogyakarta.

Sambodo, Ahmad Priyo dan Muhammad Anggri Setiawan. (2016). Perhitungan nilai ambang batas erosi dengan metode modified productivity index di DAS Bompon Kabupaten Magelang, Jurnal Geografi UGM. Yogyakarta

Sarimai, Andi. (2017). Analisis Karakteristik Sedimentasi Sungai Bialo dengan Aplikasi Surface Water Modeling System. (Skripsi Program Studi Teknik Sipil Universitas Hasanuddin). Universitas Hasanuddin, Makassar.

Sembiring, Amelia Ester, T. Mananoma, F. Halim dan E.M. Wuisan. (2014). Analisis sedimentasi di Muara Sungai Panasen. Jurnal Sipil Statik Universitas Sam Ratulangi Manado,Vol.2 No.3, Maret 2014 (148154), ISSN 2337-6732. 